\title{
Indonesian Journal of Chemical Research
}

\section{Analisis Kandungan Logam Nikel (Ni) dalam Air Laut dan Persebarannya di Perairan Teluk Kendari, Sulawesi Tenggara}

\section{Analysis of Nickel (Ni) Metal Content in Seawater and Its Distribution in Kendari Bay, Southeast Sulawesi}

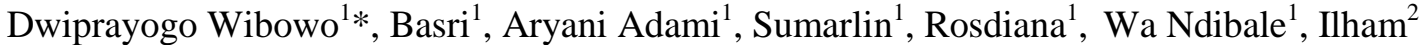 \\ ${ }^{1}$ Program Studi Teknik Lingkungan, Fakultas Teknik, Universitas Muhammadiyah Kendari, J1. K.H. Ahmad Dahlan No. 10 \\ Wowawanggu, Kec. Kadia, Kota Kendari 93127 - Sulawesi Tenggara, Indonesia. \\ ${ }^{2}$ Fakultas Teknik, Universitas Halu Oleo, Jl. HEA Mokodompit Kampus Baru UHO, Kendari 93231 \\ Sulawesi Tenggara, Indonesia. \\ *Corresponding Author: dwiprayogowibowo@yahoo.com
}

Received: 2020

Received in revised:

Accepted:

Available online:

\begin{abstract}
This study presents several correlations between community activity and the level of $\mathrm{Ni}$ metal content around Kendari Bay was analyzed using atomic absorption spectroscopy $(A A S)$ instrumentation. The 5 different location points were chosen based on the number of community activities. Furthermore, each sample was taken as much as 1 liter as far as $\pm 100 \mathrm{~m}$ from the coastline then analyzed using the AAS instrument. The results showed that there was a relationship between community activities and the high content of Ni metal which accumulated in the seawater of Kendari Bay. The Ni metal content obtained varied of $T 1<T 4<T 3<T 2>T 5$, namely 0.047; 0.052;0.063;0.068; 0.073, respectively. Based on the quality standard, the Ni content in seawater is $0.05 \mathrm{mg} / \mathrm{L}$ refers to the Ministry of Environment so that at T2, T3, T4, and T5 are exceeded the threshold. It is due to the high community activities so that the probability of Ni metal value also increases from waste disposal. Based on this study, it provides the latest information in 2020 regarding areas of Ni metal contamination due to community activities and also for the community not to consume fish obtained from Kendari Bay.
\end{abstract}

Keywords: Kendari bay, metal, AAS, nickel, population.

\begin{abstract}
Abstrak (Indonesian)
Studi ini menyajikan beberapa korelasi antara aktivitas masyarakat dengan kadar logam Nikel (Ni) di sekitar Teluk Kendari yang dianalisis menggunakan instrumentasi spektroskopi serapan atom (SSA). 5 titik lokasi berbeda dipilih berdasarkan jumlah kegiatan masyarakat. Selanjutnya setiap sampel diambil sebanyak 1 liter sejauh $\pm 100 \mathrm{~m}$ dari garis pantai dan dianalisis menggunakan instrumen SSA. Hasil penelitian menunjukkan bahwa adanya hubungan antara aktivitas masyarakat dengan tingginya kandungan logam Ni yang terakumulasi di perairan laut Teluk Kendari. Kadar logam Ni yang diperoleh bervariasi masing-masing $\mathrm{T} 1<\mathrm{T} 4<\mathrm{T} 3<\mathrm{T} 2>\mathrm{T} 5$, yaitu 0,047; 0,052; 0,063; 0,068; 0,073. Berdasarkan baku mutu, kadar $\mathrm{Ni}$ dalam air laut adalah $0,05 \mathrm{mg} / \mathrm{L}$ mengacu pada Peraturan KLH sehingga pada T2, T3, T4, dan T5 sudah melebihi ambang batas. Hal ini dikarenakan aktivitas masyarakat yang tinggi sehingga kemungkinan nilai logam $\mathrm{Ni}$ juga meningkat dari pembuangan limbah. Berdasarkan kajian ini memberikan informasi terkini ditahun 2020 mengenai kawasan pencemaran logam Ni akibat aktivitas masyarakat agar tidak mengkonsumsi ikan yang diperoleh dari perairan Teluk Kendari.
\end{abstract}

Kata Kunci: Teluk, Kendari, logam, AAS.Nikel, Penduduk.

\section{PENDAHULUAN}

Wilayah perairan merupakan suatu wilayah yang dinamis dan identik dengan tempat berkumpulnya masa air (Anggraeni dkk., 2015; Kartika dkk., 2020). Hal ini tentu didasari oleh keberadaan siklus hidrologi alam yang selalu bersirkulasi dan tidak pernah 
berhenti dari atmosfer bumi (Suntana, 2018). Ketika terjadi proses presipitasi, air hujan akan turun dan mengalir membawa beberapa unsur-unsur kimia yang bermanfaat atau dapat membawa bencana bagi umat manusia (Sunarsa, 2018). Aliran air ini akan kembali menuju ke laut untuk melanjutkan siklus hidrologi dengan membawa beberapa unsur kimia terlarut yang akan terakumulasi di perairan (Soegianto, 2019). Tidak heran bahwa beberapa zat-zat pencemar baik dari limbah domestik dan industri juga terbawa melalui aliran sungai atau drainase perkotaan menuju ke wilayah laut/teluk. Hal ini jelas akan menimbulkan pencemaran lingkungan dan efek racun bagi biota makhluk hidup lainnya (Awal dkk., 2015; Ningsih, 2018). Akibat adanya logam berat dalam perairan dapat mengakibatkan kerusakan dan kematian pada biota laut bila secara terus menerus terakumulasi dengan logam berat (Teheni dkk., 2016). aktivitas masyarakat terkait kegiatan hiburan dan industri memungkinkan tingkat pencemaran logam renik semakin meningkat (Fiskanita dkk., 2018). Tentu kondisi ini juga akan berdampak pada persebaran unsur logam di Sultra baik yang dapat ditemukan di daerah pesisir maupun daratan sehingga memungkinkan tingginya pencemaran logam berat terakumulasi dalam bentuk sedimen atau ion-ion terlarut dalam air (Haryadi, 2016; Mandasari dkk., 2019). Diperparah lagi ketika memasuki musim penghujan daerah Sultra selalu mengalami banjir kiriman dari wilayah pegunungan akibat kegiatan pertambangan, pembukaan lahan kelapa sawit, dan perkebunan. Tentu seiring dengan bertambahnya waktu peningkatan pencemaran ini juga terus meningkat (Hidayat, 2015).
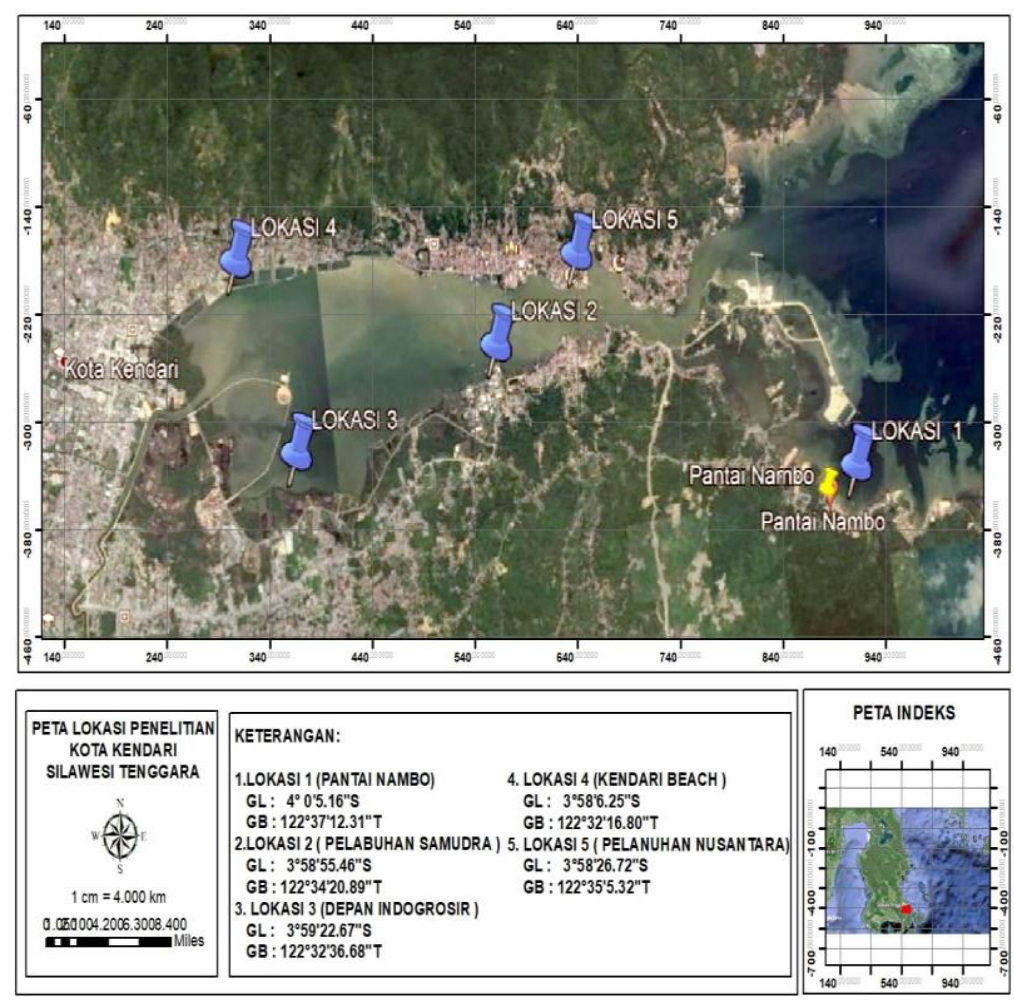

Gambar 1. Denah lokasi titik pengambilan sampel di perairan Teluk Kendari

Terkhusus di Provinsi Sulawesi Tenggara (Sultra) Indonesia merupakan salah satu wilayah yang memiliki kandungan unsur logam berlimpah di Dunia yang dibuktikan dengan banyaknya perusahaan tambang nikel (Ni) yang tersebar diberbagai wilayah Kabupaten di Sultra (Muzakkar dkk., 2019; Nurdin dkk., 2016; Nurdin dkk., 2016; Nurhidayani dkk., 2017). Selain itu didukung juga dengan maraknya
Beberapa cara telah dilakukan oleh pemerintah untuk mengatasi banjir selain mengungsikan para masyarakat yang tinggal dibantaran sungai-sungai besar juga dibuat beberapa bendungan untuk mengurangi debet aliran sungai (DAS) (Pua dkk., 2019; Purwanto dkk., 2017). Aliran air di Sultra melalui beberapa sungai besar yang tersebar di empat kabupaten dan sebagian besar bermuara ke pesisir 
timur Perairan Kendari dan Laut Banda. Sungaisungai tersebut antara lain adalah Sungai Lasolo, Sungai Roraya, Sungai Sampolawa, Sungai Wandasa, Sungai Kabangka Balano dan Sungai Laeya.

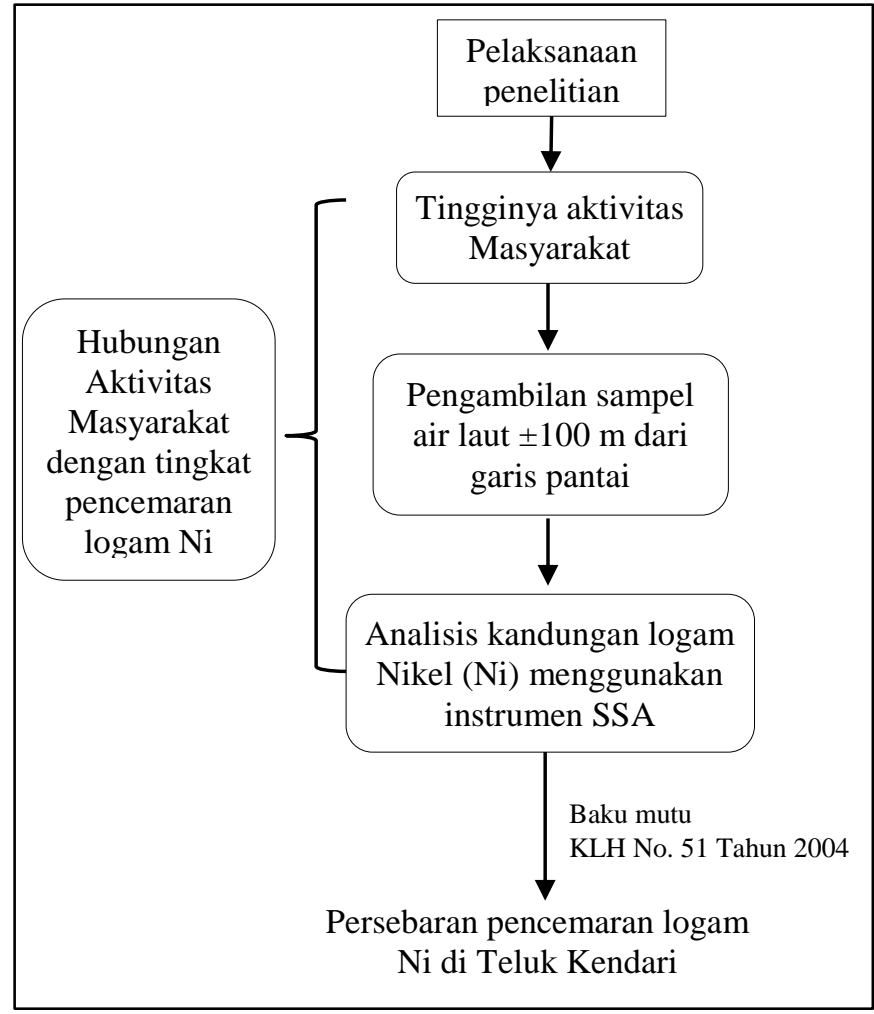

Gambar 2. Diagram alir kajian analisis kualitas air perairan teluk kendari

Aliran sungai-sungai tersebut melintasi berbagai kawasan, antara lain kawasan permukiman, pertanian dan industri/pertambangan, sehingga banyak membawa lumpur/sedimen dan kontaminan yang bersifat toksik ke Perairan Teluk Kendari (Lesmana dkk., 2019; Sentosa dan Satria, 2015). Logam berat yang terakumulasi di perairan dapat mengkontaminasi manusia melalui rantai makanan. Logam berat dalam kadar yang rendah dibutuhkan oleh organisme perairan, namun dalam kadar tinggi yang melebih nilai ambang batas dapat bersifat racun dan mengganggu kesehatan (Hananingtyas, 2017; Ketaren dkk., 2019).

Logam berat merupakan salah satu bahan kimia beracun yang dapat memasuki ekosistem bahari dan seringkali memasuki rantai makanan dan berpengaruh pada hewan-hewan, serta dari waktu ke waktu dapat berpindah-pindah dari sumbernya (Mariwy dkk., 2020; Tanasale dkk., 2018). Keberadaan perairan pesisir sebagai penampungan terakhir bagi sungai yang bermuara dan membawa limbah, baik yang berasal dari industri maupun rumah tangga, sangat membahayakan bagi masyarakat yang bertempat tinggal di sekitarnya, utamanya masyarakat yang mengkonsumsi hasil laut yang telah terkontaminasi logam berat (Galib dkk., 2017; Triantoro dkk., 2018).

Tabel 1. Lokasi dan titik pengambilan sampel di perairan Teluk Kendari

\begin{tabular}{|c|c|c|c|}
\hline Titik & Lokasi & $\begin{array}{l}\text { Lintang } \\
\text { Selatan }\end{array}$ & Bujur Timur \\
\hline $\mathrm{T} 1$ & $\begin{array}{l}\text { Pesisir Pantai } \\
\text { Nambo } \\
\text { Pelabuhan }\end{array}$ & $4^{\circ} 0{ }^{\prime} 5.16^{\prime \prime} \mathrm{S}$ & $122^{\circ} 37^{\prime} 12.31^{\prime \prime} \mathrm{T}$ \\
\hline $\mathrm{T} 2$ & $\begin{array}{c}\text { Perikanan } \\
\text { Samudera } \\
\text { Wisata }\end{array}$ & $3^{\circ} 58^{\prime} 55.46^{\prime \prime} \mathrm{S}$ & $122^{\circ} 34^{\prime} 20.89^{\prime \prime} \mathrm{T}$ \\
\hline $\mathrm{T} 3$ & $\begin{array}{l}\text { Agribisnis } \\
\text { Kendari }\end{array}$ & $3^{\circ} 59^{\prime} 22.67^{\prime \prime} \mathrm{S}$ & $122^{\circ} 32^{\prime} 36.68^{\prime \prime} \mathrm{T}$ \\
\hline $\mathrm{T} 4$ & $\begin{array}{l}\text { Kendari } \\
\text { Beach } \\
\text { Pelabuhan }\end{array}$ & $3^{\circ} 58^{\prime} 26.72^{\prime \prime} \mathrm{S}$ & $122^{\circ} 32^{\prime} 16.80^{\prime \prime} \mathrm{T}$ \\
\hline T5 & $\begin{array}{l}\text { Nusantara } \\
\text { Kendari }\end{array}$ & $3^{\circ} 58^{\prime} 26.72^{\prime \prime} \mathrm{S}$ & $122^{\circ} 35^{\prime} 5.32^{\prime \prime} \mathrm{T}$ \\
\hline
\end{tabular}

Dengan demikian pentingnya wilayah perairan untuk terus dikaji kualitas airnya agar tidak mengalami dampak pencemaran lingkungan yang serius untuk kedepannya. Sehingga dalam penelitian ini, telah dikaji hubungan aktivitas keramaian kegiatan masyarakat terhadap tingginya kandungan logam Ni yang terakumulasi dalam air laut Teluk Kendari, dengan harapan bahwa memberikan informasi terkini terkait wilayah pencemaran lingkungan akibat akumulasi logam berat dan juga bagi masyarakat agar tidak mengkonsumsi ikan yang diperoleh dari Teluk Kendari.

\section{METODOLOGI}

\section{Titik Pengambilan Sampel}

Pada penelitian ini pengambilan sampel dilakukan di perairan Teluk Kendari, yang diambil berdasarkan 5 titik lokasi berbeda seperti yang ditunjukkan pada Tabel 1 dan Gambar 1.

\section{Penyiapan Sampel}

Sampel air sebanyak 1 Liter diambil berdasarkan setiap titik yang ditentukan di perairan Teluk Kendari dengan kriteria yang ditetapkan (SNI 6964.8:2015) sejauh \pm 100 meter dari garis pantai yang bertujuan agar data yang diperoleh benar-benar valid untuk melihat kondisi akumulasi kandungan logam berat di Teluk Kendari. Selanjutnya sampel air dipreparasi untuk penyiapan analisis kadar Ni skala laboratorium yakni dengan cara sampel air masing-masing diambil 
sebanyak $500 \mathrm{~mL}$ dan dimasukkan dalam wadah beaker kemudian diteteskan sebanyak 5 tetes larutan $\mathrm{HNO}_{3}$ pekat dan panaskan diatas hotplate dengan suhu $100^{\circ} \mathrm{C}$ selama 10 menit. Setelah sampel telah dingin selanjutnya masuk ketahap penentuan konsentrasi menggunakan instrmentasi SSA pada panjang gelombang Ni 232,0 nm (SNI 6989.18:2009). Alur penelitian dapat dilihat pada Gambar 2.

\section{HASIL DAN PEMBAHASAN}

\section{Persebaran Logam Nikel}

Pentingnya mengetahui persebaran kandungan logam nikel $(\mathrm{Ni})$ karena beberapa zat-zat pencemar baik dari limbah domestik dan industri terbawa melalui aliran sungai dan drainase perkotaan terakumulasi di Teluk Kendari. Berdasarkan penelitian Fiskanita dkk. (2018) bahwa wilayah perairan air laut sangat mudah tercemar oleh logamlogam berat. Sebelum dilakukannya analisis menggunakan instrumentasi SSA, sampel diambil menggunakan botol ukuran 1 Liter dengan 5 titik lokasi berbeda yaitu (T1) Pelabuhan Perikanan Samudera (T2) Wisata Agribisnis Kendari (T3) Masjid Al-Alam (T4) Kendari Beach (T5) Pelabuhan Nusantara Kendari (Tabel 1). Pengambilan sampel berjarak \pm 100 dari garis pantai dengan kedalaman 1 meter yang diambil dengan waktu bersamaan di pagi hari bertujuan agar data yang diperoleh benar-benar valid untuk melihat kondisi akumulasi kandungan logam berat di Teluk Kendari. menghilangkan zat-zat pengganggu yang terdapat dalam sampel air (Nugraheni dkk., 2018). Hasil analisis SSA dari air laut Teluk Kendari dapat dilihat pada Tabel 2. Hasil Tabel 2 menunjukkan bahwa kandungan logam nikel di perairan Teluk Kendari pada tiap titik sangat bervariasi. Jika dibandingkan dengan nilai baku mutu berdasarkan KLH No. 51 Tahun 2004 (KLH, 2018) dengan batas maksimum kandungan logam terlarut $\mathrm{Ni}$ sebesar $0,05 \mathrm{mg} / \mathrm{L}$ untuk biota laut menunjukkan bahwa perairan Teluk Kendari pada titik T1 $<0,047 \mathrm{mg} / \mathrm{L}$ masih dibawah batas maksimum sedangkan, T2 $>0,068 \mathrm{mg} / \mathrm{L}, \mathrm{T} 3>$ $0,063 \mathrm{mg} / \mathrm{L}, \mathrm{T} 4>0,052 \mathrm{mg} / \mathrm{L}$ dan T5 < 0,073 mg/L telah melebihi ambang batas yang ditetapkan.

Walaupun T1 kurang dari $0,05 \mathrm{mg} / \mathrm{L}$ hal ini menunjukkan bahwa kondisi juga mulai mengalami pencemaran. Sedangkan jika dibandingkan dengan baku mutu untuk pemanfaatan wisata bahari kondisi ini tidak tergolong dalam melebihi ambang batas yakni dengan standar yang ditetapkan yaitu 0,075 $\mathrm{mg} / \mathrm{L}$. Ini menunjukkan bahwa perairan Teluk Kendari sudah melebihi baku mutu KLH untuk biota laut dikategorikan tercemar ringan karena hasil analisis dengan baku mutu menunjukkan nilai yang tidak terlalu signifikan dalam rentang $0,045<0,050<$ $0,075 \mathrm{mg} / \mathrm{L}$. Sedangkan baku mutu untuk wisata bahari masih sesuai dengan baku mutu KLH dan dikategorikan belum tercemar dalam kisaran $0,045<$ $0,075 \mathrm{mg} / \mathrm{L}$.

Tabel 2. Hasil Analisis Kadar Ni di Perairan Teluk Kendari

\begin{tabular}{|c|c|c|c|c|c|}
\hline \multirow[b]{2}{*}{ Titik Lokasi } & \multirow[b]{2}{*}{ Sampel } & \multirow{2}{*}{$\begin{array}{l}\text { Baku Mutu } \\
\text { Biota Laut }\end{array}$} & \multirow{2}{*}{$\begin{array}{c}\text { Baku Mutu } \\
\text { Wisata Bahari }\end{array}$} & \multicolumn{2}{|c|}{ Parameter } \\
\hline & & & & Satuan & $\begin{array}{c}\text { Hasil } \\
\text { Pengukuran }\end{array}$ \\
\hline $\mathrm{T} 1$ & $\begin{array}{l}\text { Pelabuhan Perikanan } \\
\text { Samudera }\end{array}$ & \multirow{5}{*}{0,05} & \multirow{5}{*}{0,075} & $\mathrm{mg} / \mathrm{L}$ & 0,047 \\
\hline $\mathrm{T} 2$ & $\begin{array}{l}\text { Wisata Agribisnis } \\
\text { Kendari }\end{array}$ & & & $\mathrm{mg} / \mathrm{L}$ & 0,068 \\
\hline $\mathrm{T} 3$ & Masjid Al-Alam & & & $\mathrm{mg} / \mathrm{L}$ & 0,063 \\
\hline $\mathrm{T} 4$ & Kendari Beach & & & $\mathrm{mg} / \mathrm{L}$ & 0,052 \\
\hline T5 & $\begin{array}{l}\text { Pelabuhan Nusantara } \\
\text { Kendari }\end{array}$ & & & $\mathrm{mg} / \mathrm{L}$ & 0,073 \\
\hline
\end{tabular}

\section{Hasil analisis logam nikel}

Dalam preparasi larutan, sampel disaring menggunakan kertas saring Whatmann ukuran 150 $\mathrm{mm}$ yang bertujuan untuk menghilangkan zat-zat pengotor di dalam larutan sampel, sebab di dalam sampel masih banyak zat-zat yang kemungkinan akan mengganggu nilai dari identifikasi kandungan $\mathrm{Ni}$. Selanjutnya sampel diberikan sedikit larutan asam encer berupa $\mathrm{HNO}_{3}, \mathrm{H}_{2} \mathrm{O}_{2}$ dan amnium hidroksida yang bertujuan untuk melarutkan analit logam dan
Berdasarkan kategori pencemaran biota laut tentu hal tersebut tidak sesuai untuk kehidupan organisme perairan. Logam berat di perairan dapat menimbulkan efek toksik jika keberadaannya telah melebihi nilai ambang batas sehingga akan berdampak langsung pada organisme akuatik, ekosistem perairan juga secara tidak langsung berdampak kepada kesehatan manusia dalam pemanfaatan hasil laut disekitaran wilayah tersebut (Ramlia dan Djalla, 2018). Sifat logam berat yang sulit terurai sehingga mudah 
terakumulasi dalam lingkungan perairan juga pada beberapa kasus, dapat menyebabkan kematian baik itu kepada organisme, ekosistem ataupun manusia (Wali, 2020). Selain itu, keracunan logam berat biasanya disebabkan kebiasaan memakan makanan yang berasal dari laut misalnya ikan, kepiting dan tiram yang sudah terkontaminasi akibat cemaran logam berat di perairan. Tingginya kandungan logam Ni jika terlarut dalam badan perairan pada konsentrasi tertentu akan berubah fungsi menjadi toksik bagi kehidupan perairan dan manusia yang mengkonsumsi hasil laut tersebut.
Hal ini diperparah lagi ketika masuk musim penghujan aliran air menuju ke Teluk Kendari mengakibatkan terjadinya sedimentasi, dimana logam yang tidak mudah larut mengalami proses pengendapan air laut dan mengendap dalam bentuk sedimen. Selain mencemari perairan, logam berat juga akan mengendap pada sedimen yang mempunyai waktu tinggal (residence time) sampai ribuan tahun dan terakumulasi dalam tubuh makhluk hidup melalui beberapa jalan yaitu melalui saluran pernafasan, makanan, dan melalui kulit (Wali, 2020; Yusuf dan Nurliana, 2015). Menurut Achyani dan Weliyadi

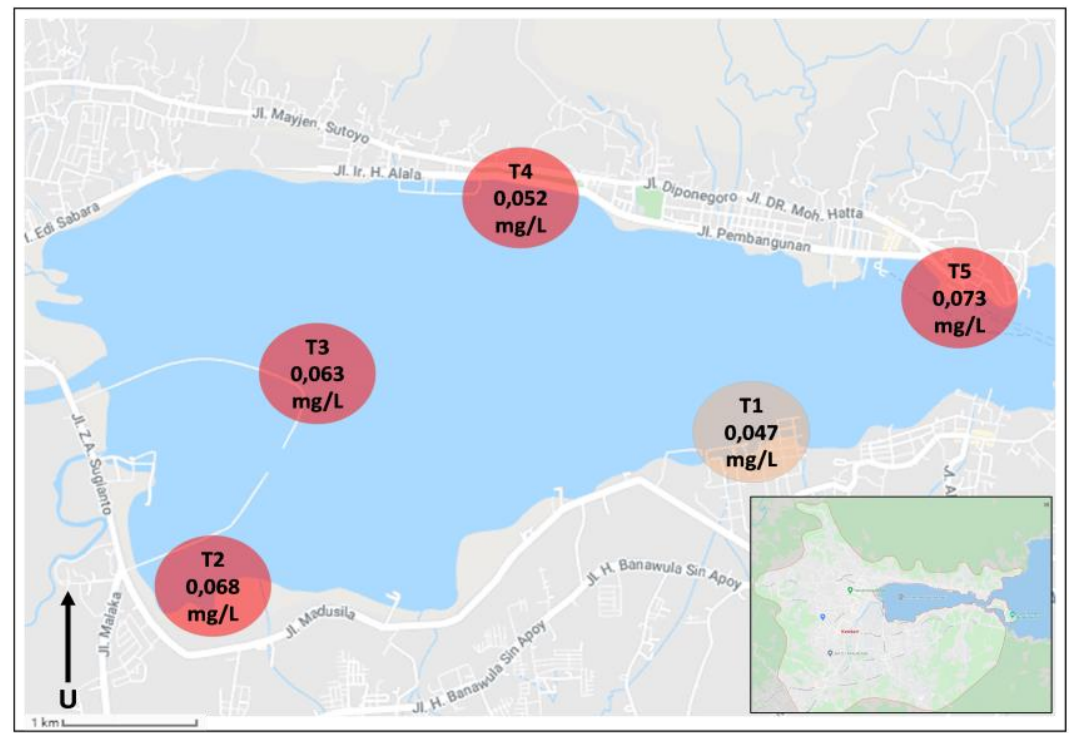

Gambar 3. Persebaran kandungan Ni di perairan Teluk Kendari (merah melebihi 0,05 mg/L, oranye kurang dari 0,05 mg/L)

\section{Pemetaan persebaran kandungan logam Ni di perairan Teluk Kendari}

Pemetaan persebaran kandungan logam $\mathrm{Ni}$ di perairan Teluk Kendari (Gambar 3) menunjukkan bahwa faktor sedimentasi dan aktivitas masyarakat mempengaruhi persebaran kandungan logam dalam Teluk Kendari. Berdasarkan penelitian Fiskanita dkk. (2018) jarak 5-10 meter dari lokasi pengambilan sampel air tidak terlalu signifikan terhadap kenaikan konsentrasi logam yang dianalisis yaitu berkisar $\pm 0,005 \mathrm{mg} / \mathrm{L}$. Kegiatan aktivitas masyarakat di $\mathrm{T} 1$ tidak terlalu padat jika dibandingkan dengan T2, T3, T4, dan T5. T2, T3, dan T4 merupakan lokasi wisata bahari yang merupakan objek wisata kuliner dan taman bakau Kota Kendari merupakan destinasi wisata yang sering dikunjungi oleh masyarakat. Hal ini tentu mengakibatkan kemungkinan masuknya limbah yang mengandung nikel di perairan. Sedangkan T5 menunjukkan lokasi bongkar muat barang di pelabuhan sehingga tentu meningkatkan beberapa limbah pencemar dalam perairan.
(2013) bahwa pencemaran lingkungan oleh nikel terjadi secara anthropogenic seperti pertambangan, peleburan, dan pemurnian logam nikel. Menurut Adam dan Maftuch (2015) bahwa peningkatan kadar nikel dalam air terjadi karena masuknya limbah yang mengandung nikel ke perairan. Tingginya konsentrasi logam $\mathrm{Ni}$ dalam lingkungan perairan dapat disebabkan oleh berbagai faktor seperti aktivitas manusia yang menghasilkan beberapa limbah rumah tangga, penggerusan batuan atau lapisan tanah serta beberapa partikel logam yang turun bersama aliran air (Wali, 2020). Beberapa penelitian yang telah dilaporkan oleh beberapa peneliti untuk mengatasi permasalahan pencemaran logam berat diperairan laut dan teluk yaitu dengan memanfaatkan tumbuhan rumput laut sebagai biosorben (Bijang dkk., 2018).

Hubungan penentuan secara kimia juga berkaitan dengan kajian parameter oseanografi fisik perairan diantaranya seperti suhu, arus, $\mathrm{pH}$ (derajat keasaman), kecerahan dan salinitas. Parameter oseanografi fisik pada dasarnya dapat mempengaruhi konsentrasi 
logam berat di perairan. Suhu dan salinitas serta faktor fisika lainnya sangat mempengaruhi proses kelarutan akan logam-logam berat yang masuk ke perairan. Selain itu, logam berat dalam suatu lingkungan baik itu air maupun sedimen dapat melalui banyak proses akumulasi yaitu secara fisik, kimia dan biologis. Secara umum kandungan logam berat pada sedimen lebih tinggi dibanding yang terdapat pada air laut (Hutagalung, 1984; Male dkk., 2017). Logam berat mempunyai sifat mengikat bahan organik dan mengendap di dasar perairan dan bersatu dengan sedimen sehingga kadar logam berat dalam sedimen lebih tinggi dibanding dalam air (Amriarni dkk., 2011; Nugraha, 2009). Oleh sebab itu, tingginya sedimentasi dan logam $\mathrm{Ni}$ yang terjadi di Teluk Kendari pemerintah telah berupaya membuat beberapa talud untuk pemisahan sedimentasi walaupun belum optimal dan menghimbau para nelayan untuk tidak mengkonsumsi beberapa organisme laut dari Teluk Kendari.

\section{KESIMPULAN}

Hasil yang diperoleh menunjukkan bahwa adanya hubungan aktivitas keramaian kegiatan masyarakat terhadap tingginya kandungan logam $\mathrm{Ni}$ yang terakumulasi dalam air laut Teluk Kendari. Kandungan logam $\mathrm{Ni}$ yang diperoleh bervariasi berturut-turut $\mathrm{T} 1<\mathrm{T} 4<\mathrm{T} 3<\mathrm{T} 2>\mathrm{T} 5$ yaitu 0,047 ; 0,052; 0,063; 0,068; 0,073. Berdasarkan baku mutu, standar kandungan $\mathrm{Ni}$ dalam air laut sebesar 0,05 mg/L, sehingga pada T2, T3, T4, dan T5 dinyatakan telah melebihi ambang batas. Tingginya konsentrasi logam Ni dalam lingkungan perairan Teluk Kendari disebabkan oleh berbagai faktor seperti aktivitas manusia yang menghasilkan beberapa limbah rumah tangga, penggerusan batuan atau lapisan tanah dari aktivitas pembukaan lahan baru dan pertambangan di sekitaran Kota Kendari.

\section{UCAPAN TERIMAKASIH}

Para penulis mengucapkan terima kasih kepada Laboratorium Forensik - Universitas Halu Oleo atas bantuan analisis menggunakan instrumentasi SSA.

\section{DAFTAR PUSTAKA}

Achyani, R. dan Weliyadi, E. 2013. Analisis dan Evaluasi Kontaminasi Logam Berat pada Sedimen, Air dan Rumput Laut Euchema Cottoni di Kota Tarakan, J. Harpodon Borneo, 6, 1-6.

Adam, M.A. dan Maftuch, M., 2015. Evaluasi Optimasi Instalasi Pengolahan Air Limbah Terhadap Pencemaran Sungai Wangi Pasuruan,
J. Environ. Eng. Sustain. Technol., 2, 1-5.

Amriarni, A, Hendrarto B. dan Hadiyarto A., 2011. Bioakumulasi logam berat timbal $(\mathrm{Pb})$ dan seng (Zn) pada kerang darah (Anadara granosa L.) dan kerang bakau (Polymesoda bengalensis L.) di perairan Teluk Kendari, J. Ilmu Lingkung., 9, 45-50.

Anggraeni, T.D., Wulandari, S.Y. dan Marwoto, J., 2015. Kajian Konsentrasi Nitrat Dan Silikat Pada Kondisi Pasang Dan Surut Di Perairan Morosari Kabupaten Demak, J. Oceanogr., 4, 635-640.

Awal, J., Tantu, H. dan Tenriawaru. E.P., 2015. Identifikasi Alga (Algae) Sebagai Bioindikator Tingkat Pencemaran di Sungai Lamasi Kabupaten Luwu, Dinamika, 5, 21-34.

Bijang, C.M., Tehubijuluw, H. dan Kaihatu, T.G., 2018. Biosorption Of Cadmium $\left(\mathrm{Cd}^{2+}\right)$ Metal Ion In Brown Seaweed Biosorbent (Padina australis) From Liti Beach, Kisar Island, Indo. J. Chem. Res., 6, 563-570.

Fiskanita, F., Hamzah, B. dan Supriadi, S., 2018. Analisis Logam Timbal (Pb) Dan Besi (Fe) Dalam Air Laut Di Pelabuhan Desa Paranggi Kecamatan Ampibabo, J. Akad. Kim., 4, 175180.

Galib, S., Said, I. dan Napitupulu, M., 2017. Digesti Logam Zink (Zn) Dalam Sedimen Estuaria Sungai Palu Dengan Kombinasi Asam Mineral, J. Akad. Kim., 6,247-251.

Hananingtyas, I., 2017. Studi Pencemaran Kandungan Logam Berat Timbal $(\mathrm{Pb})$ dan Kadmium (Cd) pada Ikan Tongkol (Euthynnus sp.) di Pantai Utara Jawa, Biotropic, 1, 41-50.

Haryadi, H., 2016. Analisis Dampak Pembangunan Smelter Nikel terhadap Perekonomian Daerah di Provinsi Sulawesi Tenggara, Bul. Sumber Daya Geol., 11, 25-39.

Hidayat, H., 2015. Pengelolaan Hutan Lestari: Partisipasi, Kolaborasi dan Konflik, Yayasan Pustaka Obor Indonesia.

Hidup, M.L., 2018. Keputusan Menteri Negara Lingkungan Hidup Nomor 51 Tahun 2004. Tentang Baku Mutu Air Laut Untuk Biota, Jakarta: MENLH. ,

Hutagalung, H.P., 1984. Logam berat dalam lingkungan laut, Pewarta Ocean. IX, 1, 45-59.

Kartika, D.D., Novitasari, D,C,R. dan Setiawan F., 2020. Prediksi Kecepatan Arus Laut di Perairan Selat Bali menggunakan Metode Exponential Smoothing Holt-Winters, MathVision, 2, 12-17.

Ketaren, C.B.B., Hakim, A.A. dan Fahrudin A., 2019, Wardiyatno Y. Kandungan Logam Berat $\mathrm{Pb}$ Undur-Undur Laut dan Implikasinya Pada 
Kesehatan Manusia, J. Biol. Trop., 19, 90-100.

Lesmana D.M.M, Waterman W. dan Maimina M., 2019. Kajian Teknis Sistem Penyaliran Tambang Terbuka pada PIT Alpha PT. Timah Investasi Mineral, Kecamatan Kabaena Barat, Kabupaten Bombana, Sulawesi Tenggara, Prosiding Seminar Nasional Sains dan Teknologi Terapan. 501-506.

Male Y.T, Malle D. dan Bijang C.M., 2017. Analysis of Cadmium $(\mathrm{Cd})$ and Lead $(\mathrm{Pb})$ Metals Content On Sediment Inner Part of Ambon Bay, Indo. J. Chem. Res., 5, 434-443.

Mandasari J, Andarani P. dan Sarminingsih A., 2019. Analisis Pengaruh Kebisingan Terhadap Daya Pendengaran Pekerja di FeNi Plant PT. ANTAM (Persero) Tbk. Unit Bisnis Pertambangan Nikel Sulawesi Tenggara, J. Tek. Lingkung., 6, 1-11.

Mariwy, A., Dulanlebit, Y.H. dan Yulianti, F., 2020. Awar-awar (Ficus Septica Burm F) Heavy Metal Mercury Accumulation Study Using Awar-awar (Ficus Septica Burm F) Plants, Indo. J. Chem. Res., 7, 159-169.

Muzakkar, M.Z., Nurdin, M., Ismail, I,, Maulidiyah., M., Wibowo, D., Ratna, R., Saad, S.K.M. dan Umar, A.A., 2019. $\mathrm{TiO}_{2}$ Coated-Asphalt Buton Photocatalyst for High-Performance Motor Vehicles Gas Emission Mitigation, Emiss. Control Sci. Technol., 6, 28-36.

Ningsih, R.W., 2018. Dampak Pencemaran Air Laut Akibat Sampah Terhadap Kelestarian Laut Indonesia, J. Univ. Muhammadiyah Yogyakarta, $1,1-12$.

Nugraha, W.A., 2009. Kandungan logam berat pada air dan sedimen di perairan socah dan kwanyar kabupaten bangkalan, J. Kelaut. Indones. J. Mar. Sci. Technol., 2, 158-164.

Nugraheni, Z.V., Utomo, W,P., A'yuni, Q., Agustina, N.A., Kholik, J. dan Puspita, C., 2018, Penggunaan Pektin Kulit Jeruk Manis (Citrus sinesis) sebagai Absorben untuk Mengurangi Kadar Ion Kromium (VI) pada Sampel Air Sungai Jagir, Akta Kim. Indones., 3, 112-120.

Nurdin, M., Maulidiyah, A.H.W., Abdillah, N. dan Wibowo, D., 2016a. Development of extraction method and characterization of $\mathrm{TiO}_{2}$ mineral from ilmenite, Int. J. ChemTech Res, 9, 483-491.

Nurdin, M., Zaeni, A., Maulidiyah, Natsir, M., Bampe, A. dan Wibowo. D., 2016b. Comparison of conventional and microwave-assisted extraction methods for $\mathrm{TiO}_{2}$ recovery in mineral sands, Orient. J. Chem., 32, 2713-2721.

Nurhidayani, Muzakkar, M.Z., Maulidiyah, Wibowo, D. dan Nurdin, M., 2017. A Novel Of Buton
Asphalt and Methylene Blue As Dye-Sensitized Solar Cell Using $\mathrm{TiO}_{2} / \mathrm{Ti}$ Nanotubes Electrode, IOP Conf. Ser. Mater. Sci. Eng., 267, 12035.

Pua, M., Sumarauw, J.S.F. dan Manoppo, F.J., 2019, Kajian Efisiensi Pembangunan Waduk Kuwil Untuk Reduksi Banjir Di Manado Akibat Sungai Tondano, J. Ilm. Media Eng., 7, 908-919.

Purwanto, P.I., Juwono, P.T. dan Asmaranto, R., 2017, Analisa Keruntuhan Bendungan Tugu Kabupaten Trenggalek, J. Tek. Pengair., 8, 222230.

Ramlia, R. dan Djalla, A., 2018. Uji Kandungan Logam Berat Timbal $(\mathrm{Pb})$ di Perairan Wilayah Pesisir Parepare, J. Ilm. Mns. Dan Kesehat., 1, 255-264.

Sentosa, A.A. dan Satria, H., 2015. Kebiasaan makan beberapa jenis ikan yang tertangkap di rawa kaiza Sungai Kumbe Kabupaten Merauke, Papua, LIMNOTEK-Perairan Darat Trop. di Indones., 22, 32-41.

Soegianto, A., 2019. Ekologi Air Tawar, Airlangga University Press.

Sunarsa, S., 2018. Isyarat Sains Tentang Air Dalam Al-Qur'an, J. Naratas, 1, 9-18.

Suntana, I., 2018. Keabadian Air: Telaah Teologi Energi dalam Islam dan Hukum Termodinamika. Afkaruna Indones, Interdiscip. J. Islam. Stud., 14, 242-261.

Tanasale, M.F.J.D.P., Bandjar, A. dan Sewit, N., 2018. Isolasi Kitosan Dari Tudung Jamur Merang (Vollvariella Volvaceae) Dan Aplikasinya Sebagai Absorben Logam Timbal (Pb), Indo. J. Chem. Res., 6, 44-50.

Teheni, M.T., Nafie. N. La. dan Dali, S., 2016. Analysis of Heavy Metal $\mathrm{Cd}$ at AlgaeE Eucheuma cottoni in Bantaeng Region Coastal, Ind. J. Chem. Res., 4, 348-351.

Triantoro, D.D., Suprapto, D. dan Rudiyanti, S., 2018. Kadar Logam Berat Besi (Fe), Seng (Zn) Pada Sedimen Dan Jaringan Lunak Kerang Hijau (Perna viridis) Di Perairan Tambak Lorok Semarang, J. Manag. Aquat. Resour., 6, 173180.

Wali, W., 2020. Kandungan Logam Berat Nikel (Ni) pada Sedimen dan Air Di Perairan Desa Tapuemea Kabupaten Konawe Utara, J. Sapa Laut (Jurnal Ilmu Kelautan), 5, 37-47.

Yusuf, B. dan Nurliana, S., 2015. Analisa $\mathrm{Pb}^{2+}$ Pada Lobster (Panulirus SP) Dengan Metode Adisi Standar Spektrofotometer Uv-Vis Menggunakan Pengompleks Ditizon, J. Kim. Mulawarman, 11, 56-58. 